\title{
KAJIAN POTENSI EKOWISATA BERBASIS PERIKANAN DI KECAMATAN GLAGAH DAN LICIN, KABUPATEN BANYUWANGI, JAWA TIMUR
}

\author{
Maheno Sri Widodo $^{\mathrm{a}}$, Bayu Kusuma ${ }^{\mathrm{a}, *}$, Fani Fariedah ${ }^{\mathrm{a}}$ \\ ${ }^{a}$ Fakultas Perikanan dan Ilmu Kelautan, Universitas Brawijaya, Malang, 65145 \\ *Corresponding author: bayu_kusuma@ub.ac.id
}

\begin{abstract}
Abstrak
Kecamatan licin dan Kecamtan Glagah merupakan dua kecamatan di Kabupaten Banyuwangi yang terletak pada jalur menuju wisata kawah ijen. Kedua kecamatan tersebut mempunyai tiga desa yang tergolong sebagai desa tertinggal menurut data Indeks Desa Membangun tahun 2015. Tujuan dari penelitian ini adalah untuk memetakan potensi ekowisata berbasis perairan pada desa tertinggal di kedua kecamatan tersebut berdasarkan metode analisis SWOT (Strength, Weak, Opportunities, Threat) yang dimodifikasi secara kualitatif dan kuantitatif guna pengembangan potensi desa. Analisis SWOT menghasilkan pengembangan potensi pariwisata desa Kenjo (Kecamatan Glagah) di bidang pertanian, Desa Gumuk (Kecamatan Licin) di bidang perairan dan Desa Banjar (Kecamatan Licin) di bidang kuliner.
\end{abstract}

Kata Kunci: Ekowisata, Glagah, Licin, Kecamatan, Perairan

\begin{abstract}
Licin and Glagah district located at Banyuwangi Regency and lies on Ijen Creater tourism area. Both of those districts have 3 villages, which classified as low poverty village based on "Indeks Desa Membangun2015". The aim of the research is to identify water based ecotourism potency of low poverty village on both districts based on SWOT analysis modified method. SWOT analysis results are Kenjo village (Glagah District) suitable for agriculture based tourism area, Gumuk village (Licin District) suitable for fisheries based tourism area and Banjar village (Licin District) suitable for culinary based tourism area.
\end{abstract}

Keywords: Ecotourism, District, Glagah, Licin, Water

\section{PENDAHULUAN}

Kabupaten Banyuwangi memiliki kebijakan terkait pengembangan wilayah dibidang pariwisata. Guna mendukung kebijakan pengembangan wilayah, Kabupaten Banyuwangi membangun berbagai infrastruktur guna mendukung pengembangan industry pariwisata [1]. Salah satu ikon pariwisata Kabupaten Banyuwangi yang banyak diminati wisatawan asing maupun lokal adalah kawasan wiata Kawah Ijen. Kawasan wisata tersebut dapat dicapai menggunakan kendaraan roda dua maupun roda empat melewati Kecamatan Glagah dan Licin [2]. Status desa tertinggal yang berada di kedua Kecamatan tersebut menjadi masalah serius yang harus dipecahkan, mengingat desa yang tertinggal berada pada jalur menuju kawasan wisata yang telah dikenal luas [3].
Pengembangan sektor pariwisata berbasis potensi wilayah merupakan sebuah konsep yang terbukti mampu mendorong pengembangan wilayah secara positif dari berbagai perspektif. Konsep tersebut harus dikembangkan secara detail dengan pendekatan yang jelas dan efektif sehingga tercapai sebuah sinergi antara pengembangan potensi wilayah dengan keinginan masyarakat lokal [4]. Pengembangan sektor pariwisata pada desa tertinggal berbasis perairan dipilih dengan dasar bahwa wilayah target mempunyai banyak DAS (daerah aliran sungai) dengan pasokan air yang konstan sepanjang tahun. DAS tersebut berasal dari mata air gunung Ijen yang mengalir melalui Kecamatan Glagah [5] dan Licin [6].

Tujuan dari penelitian ini adalah untuk memetakan potensi ekowisata wilayah berbasis perairan di Kecamatan Glagah dan Licin menggunakan pendekatan analisis 
SWOT dengan modifikasi khusus. Hasil dari analisis SWOT diharapkan mampu digunakan untuk pengambilan kebijakan terkait perencanaan pengembangan pariwisata daerah yang sesuai dengan karakter wilayah, terutama pada 3 desa tertinggal yang terdapat di Kecamatan Glagah dan Licin.

\section{METODE PENELITIAN}

Metode penelitian yang digunakan dalam penelitian ini adalah mixed model dengan desain exploratory menggunakan data kuantitatif dan kualitatif pada tiga desa target. Desa target yang dimaksudkan adalah desa Kenjo (Kecamatan Glagah), Desa Gumuk (Kecamatan Licin) dan Desa Banjar (Kecamatan Licin). Data kualitatif dan kuantitatif didapatkan dari pengambilan data sekunder (data dari BPS) dan data primer (pengambilan secara langsung menggunakan kuisioner dengan sampel acak tiap desa 100 orang). Data yang diambil meliputi data geografis wilayah (kuantitatif), kependudukan (kuantitatif) dan sosial-ekonomi (kualitatif dan kuantitatif). Hasil pengambilan sampel kuisioner kemudian dianalisis menggunakan uji statistik kualitatif (Chi-square) dan deskripsi statistik sederhana untuk data kuantitatif menggunakan software SPSS versi 16 untuk Windows. Hasil uji statistik kemudian digunakan sebagai bahan pertimbangan pembuatan tabel SWOT dari berbagai data yang muncul. Hasil tabel SWOT kemudian didiskusikan dengan beberapa SKPD (Satuan Kerja Perangkat Daerah) terkait guna menentukan arah kebijakan pengembangan desa tertinggal.

\section{HASIL DAN PEMBAHASAN}

\section{Data geografis wilayah}

Data geografis wilayah menunjukkan bahwa Kecamatan Glagah mempunyai luasan total $76,28 \mathrm{~km}^{2}$ yang terbagi menjadi 10 desa. Desa Kenjo yang menjadi desa target mempunyai luas wilayah $7,12 \quad \mathrm{~km}^{2}$. Kecamatan Glagah berada pada ketinggian 75-460 mdpl dan dilewati oleh 3 DAS, yakni: Sungai Kalibendo, Kalipakis dan Sungai yang mengalir dengan pasokan air konstan sepanjang tahun [5]. Sedangkan, Kecamatan Licin mempunyai luasan total wilayah seluas $82,86 \mathrm{~km}^{2}$ yang terbagi menjadi 8 desa. Desa Gumuk dan Banjar yang merupakan desa target masing-masing mempunyai luasan 5,24 dan $4,36 \mathrm{~km}^{2}$. Kecamatan Licin berada pada ketinggian 400-650 mdpl dan dilewati oleh 6 DAS, yakni: Sungai Gundang, Megoarum, Cindeh, Bungu, Secawang dan Seruni yang mengalir dengan pasokan air konstan sepanjang tahun [6].

Data geografis wilayah target menunjukkan bahwa kedua Kecamatan mendukung untuk kegiatan budidaya ikan air tawar karena mempunyai sumber air yang baik. Sumber air yang baik sangat dibutuhkan untuk usaha budidaya ikan air tawar. Usaha budidaya dengan sumber air yang baik mampu meningkatkan probabilitas keberhasilan [7]. Keberhasilan usaha yang sudah tercapai untuk kemudian dapat dikembangkan menjadi ekowisata perairan dengan konsep usaha budidaya air tawar dan turunannya. Konsep ini belum banyak diaplikasikan oleh wilayah-wilayah lain disekitarnya. Innovasi pengembangan konsep ekowisata yang mempunyai keunikan sesuai dengan karakter wilayah mampu memberikan sebuah dampak positif terhadap perkembangan industri pariwisata [8].

\section{Data kependudukan}

Kecamatan Glagah mempunyai jumlah penduduk laki-laki (18.262 jiwa) dan perempuan (18.763 jiwa) dengan total 37.028 jiwa. Kecamatan Licin mempunyai jumlah penduduk laki-laki (14.634 jiwa) dan perampuan (14.713 jiwa) dengan total 29.347 jiwa. Sebaran penduduk pada desa target dapat dilihat pada tabel 1. Sebaran penduduk memerlukan informasi untuk menunjang data mengenai sebaran tingkat pendidikan untuk mengetahui kesiapan SDM untuk pengembangan potensi ekowisata. Pengambilan data secara acak melalui kuisioner pada ketiga desa untuk mengetahui tingkat pendidikan tertinggi untuk masingmasing keluarga dilakukan. Hasil dari pengambilan data tingkat pendidikan pada 
tiap desa dapat dilihat pada tabel 2. Uji Chisquare pada sebaran tingkat pendidikan antar desa target tidak menghasilkan perbedaan nyata $(p>0,05)$. Hal ini mengindikasikan bahwa tingkat pendidikan antar desa target tidak menunjukkan kesenjangan pendidikan antar desa dimana pendidikan di desa target didominasi oleh lulusan dari SMA/SMK.

Pengetahuan dan kemampuan seorang pekerja pada industri pariwisata mutlak diperlukan. Pengetahuan dan kemampuan pekerja dibidang industry pariwisata sangat dibutuhkan, khususnya mengenai pelayanan. Pekerja mendapatkan kedua hal tersebut baik dari pendidikan formal maupun berbagai pelatihan yang diadakan, sehingga mampu meningkatkan kepuasan konsumen. Kepuasan konsumen atas pelayanan pada tempat tujuan wisata merupakan kunci keberhasilan pengembangan sebuah kawasan wisata [9].

\section{Data sosial ekonomi}

Mata pencaharian masyarakat kedua kecamatan didominasi dari sektor pertanian, sector perdagangan memberikan lapangan usaha dengan urutan kedua yang diminati oleh masyarakat. Sektor jasa menyediakan pilihan mata pencaharian ketiga masyarakat desa target dan sektor industri merupakan menyediakan pilihan terkecil lapangan usaha bagi masyarakat desa target di kedua kecamatan. Data lapangan pekerjaan dapat dilihat pada tabel 3. Masyarakat pada desa target yang masih agraris merupakan hal positif untuk usaha budidaya air tawar. Sektor pertanian dapat digunakan untuk dikombinasikan dengan usaha perikanan, sehingga mampu menambah pendapatan masyarakat [7].

Pengembangan sektor usaha perikanan menjadi sebuah kawasan ekowisata berbasis perairan memerlukan sebuah transisi yang dinamis. Kebijakan pemerintah untuk bersinergi dengan karakter masyarakat kawasan wisata menjadi kunci penting keberhasilan [4]. Salah satu perspektif budaya masyarakat yang mampu untuk mendorong keberhasilan sebuah kawasan wisata adalah kulinernya. Kuliner mampu memberikan karakter pada suatu wilayah, sehingga mampu menyuguhkan sebuah konsep dan karakter pada suatu kawasan wisata [10].

Hasil data survey mengenai masakan yang disajikan pada momen spesial menunjukkan beda nyata $(p<0,05)$ dengan uji korelasi yang cukup tinggi. Hal tersebut menunjukkan bahwa masing-masing desa mempunyai karakter masing-masing terhadap kuliner yang disajikan pada momen spesial. Desa Kenjo mempunyai karakteristik menyajikan gule, Desa Gumuk menyajikan soto dan Desa Banjar menyajikan nasi lemang. Selain itu, hasil data survei mengenai jajanan yang disajikan pada momen spesial menunjukkan beda nyata $(\mathrm{p}<0,05)$ dengan uji korelasi yang cukup tinggi. Hal tersebut menunjukkan bahwa masing-masing desa mempunyai karakter jajanan yang disajikan pada momen spesial di masing-masing desa target. Desa Kenjo dan Gumuk mempunyai karakteristik menyajikan pisang goreng, serta desa banjar menyajikan lapis lanun pada momen spesial. Hasil analisis data jajanan juga mengindikasikan perubahan budaya masyarakat, dimana kue donat yang merupakan jajanan bukan asli wilayah lokal berhasil masuk, serta mampu menggeser jajanan lokal. Hal ini mengindikasikan bahwa terjadi pergeseran budaya, khususnya kuliner masyarakat lokal. Data mengenai jenis makanan dan jajanan yang disajikan pada momen spesial dapat dilihat pada tabel 4 dan 5 .

Tabel 1. Jumlah penduduk pada desa target

\begin{tabular}{llccc}
\hline \multirow{2}{*}{ Kecamatan } & \multicolumn{1}{c}{ Desa } & \multicolumn{3}{c}{ Penduduk } \\
\cline { 3 - 5 } & & Laki-laki & Perempuan & Total \\
\hline Glagah & Kenjo & 1.094 & 1.121 & 2.215 \\
\hline \multirow{2}{*}{ Licin } & Gumuk & 1.312 & 1.250 & 2.562 \\
\cline { 2 - 5 } & Banjar & 1.221 & 1.290 & 2.511 \\
\hline
\end{tabular}


Tabel 2. Tingkat pendidikan sumberdaya manusia desa target

\begin{tabular}{llcccc}
\hline \multirow{2}{*}{ Kecamatan } & Desa & \multicolumn{5}{c}{ Jenjang pendidikan teringgi } \\
\cline { 2 - 6 } & & SD & SMP & SMA/SMK & Diploma/S1 \\
\hline Glagah & Kenjo & 10 & 13 & 72 & 5 \\
\hline \multirow{2}{*}{ Licin } & Gumuk & 11 & 18 & 64 & 7 \\
\cline { 2 - 6 } & Banjar & 0 & 0 & 87 & 13 \\
\hline
\end{tabular}

Karakter dari kuliner lokal mampu menjadi ikon sebuah tempat wisata. Kuliner lokal mampu memberikan pengalaman yang berbeda dan kenangan kepada wisatawan, sehingga mampu memunculkan rasa keinginan untuk kembali ke tempat dimana mereka menemukan karakter kuliner tersebut ${ }^{[11]}$. Wisatawan menginginkan kuliner lokal dengan intensitas yang berbeda-beda, tergantung kepada individunya. Kuliner lokal yang dimodifikasi mampu menyuguhkan inovasi yang berbeda dan memberikan karakter pada tempat wisata tersebut[12]. Kombinasi antara konsep wisata perairan dengan karakter kuliner lokal sangat diperlukan, sehingga mampu menyuguhkan sesuatu yang berbeda.

Tabel 4. Jenis makanan yang biasa disajikan pada hari spesial

\begin{tabular}{lccc}
\hline \multirow{2}{*}{ Jenis makanan } & \multicolumn{3}{c}{ Penduduk } \\
\cline { 2 - 4 } & Kenjo & Gumuk & Banjar \\
\hline Soto & 17 & 37 & 18 \\
\hline Gule & 25 & 11 & 2 \\
\hline Rendang & 0 & 11 & 3 \\
\hline Rawon & 14 & 10 & 7 \\
\hline Sate ayam & 4 & 0 & 0 \\
\hline Lodeh & 0 & 8 & 3 \\
\hline Nasi tumpeng & 5 & 8 & 4 \\
\hline Nasi campur & 3 & 15 & 5 \\
\hline Nasi kuning & 28 & 0 & 0 \\
\hline Nasi lemang & 0 & 0 & 58 \\
\hline Uyah asem & 3 & 0 & 0 \\
\hline Pecel petek & 1 & 0 & 0 \\
\hline
\end{tabular}

\section{Analisis SWOT}

Hasil analisis SWOT dari berbagai data yang masuk serta pertimbangan dari FGD (Forum Grup Discussion) antara peneliti dan SKPD terkait disajikan pada tabel 6. SKPD yang hadir di dalam FGD diantaranya adalah kepala desa dari ketiga desa target, camat
Kecamatan Glagah dan Licin, perwakilan BAPPEDA Kabupaten Banyuwangi, Dinas Pariwisata, Dinas Perikanan dan Pangan serta Dinas Pertanian. Hasil dari permasalah yang muncul dari analisis SWOT untuk kemudian dibahas bersama untuk mencari jalan alternatif guna memberikan pertimbangan terhadap arah kebijakan yang akan diambil kemudian.

Tabel 5. Jenis jajanan yang biasa disajikan pada hari spesial

\begin{tabular}{lccc}
\hline \multirow{2}{*}{$\begin{array}{c}\text { Jenis } \\
\text { makanan }\end{array}$} & \multicolumn{3}{c}{ Penduduk } \\
\cline { 2 - 4 } & Kenjo & Gumuk & Banjar \\
\hline Donat & 6 & 23 & 9 \\
\hline Sumping & 13 & 17 & 14 \\
\hline Klepon & 0 & 0 & 10 \\
\hline Klemben & 0 & 0 & 18 \\
\hline Lapis lanun & 0 & 0 & 21 \\
\hline Lemper & 1 & 4 & 11 \\
\hline Pisang goreng & 46 & 32 & 9 \\
\hline Kucur & 0 & 5 & 7 \\
\hline Bikang & 2 & 6 & 1 \\
\hline Ote-ote & 0 & 2 & 0 \\
\hline Ladrang & 5 & 2 & 0 \\
\hline Bolu kukus & 17 & 7 & 0 \\
\hline Mendhut & 0 & 2 & 0 \\
\hline Tahu isi & 10 & 0 & 0 \\
\hline
\end{tabular}

Hasil analisa SWOT menghasilkan saran untuk perancangan kebijakan terkait pengembangan desa target. Desa Kenjo merupakan desa dengan potensi pertanian, sehingga perancangan terkait arah pengembangan desa adalah sebagai Desa penyangga pangan dan pengembangan tanaman hias. Desa Gumuk merupakan desa berbasis pertanian yang berpotensi untuk ditransformasikan menjadi desa wisata berbasis perairan. Transformasi ini terkait dengan hasil musyawarah desa untuk mengembangkan potensi desa pada usaha berbasis perikanan. Pengembangan desa 
Gumuk dapat diarahkan pada usaha budidaya ikan air tawar yang dapat dikembangkan secara tumpang sari pada lahan pertanian. Desa Banjar merupakan desa yang mampu dikembangkan untuk menjadi desa dengan potensi menjadi desa wisata kuliner karena masyarakat desa Banjar mempunyai karakter kuat untuk pengembangan potensi kuliner dan rekam jejak desa yang telah dikenal dengan karakter kulinernya.

Tabel 6. Analisis SWOT

\begin{tabular}{|c|c|c|}
\hline Komponen SWOT & $\begin{array}{l}\text { Peluang (Opportunities): } \\
\begin{array}{l}\text { - } \\
\text { pendahnya kompetisi } \\
\text { pariwisata lokal } \\
\text { (berdasarkan NAC) } \\
\text { - Wisatawan asing yang } \\
\text { mulai melirik Banyuwangi } \\
\text { sebagai destinasi wisata }\end{array}\end{array}$ & $\begin{array}{l}\text { Tantangan (Threats): } \\
\text { - } \quad \begin{array}{l}\text { Kemajuan pariwisata yang } \\
\text { tak terkendali }\end{array} \\
\text { - } \quad \text { Rawan terjadinya } \\
\text { kemacetan pada tahun } \\
\text { mendatang } \\
\text { - } \quad \text { Rawan terjadinya } \\
\text { kerusakan di sektor } \\
\text { budaya } \\
\text { - Rawan terjadinya } \\
\text { kerusakan di sektor alam } \\
\end{array}$ \\
\hline $\begin{array}{l}\text { Kekuatan (Strenght): } \\
\text { - Letak strategis } 3 \text { desa } \\
\text { target (jalur menuju } \\
\text { Kawah Ijen) } \\
\text { - Karakter masing-masing } \\
\text { desa yang berpotensi } \\
\text { untuk lokasi pariwisata } \\
\text { - Potensi produk lokal yang } \\
\text { sangat tinggi }\end{array}$ & 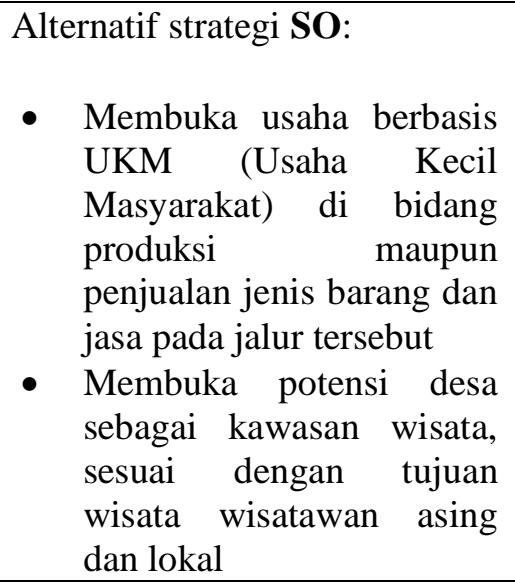 & $\begin{array}{l}\text { Alternatif Strategi ST: } \\
\text { - Diperlukan kebijakan- } \\
\text { kebijakan yang mengatur } \\
\text { pengembangan potensi } \\
\text { desa sebagai desa wisata } \\
\text { guna yang selaras dengan } \\
\text { karakter geografis, alam } \\
\text { dan budaya masing- } \\
\text { masing desa targe }\end{array}$ \\
\hline $\begin{array}{l}\text { Kelemahan (Weakness): } \\
\text { - } \begin{array}{l}\text { Lemahnya SDM yang } \\
\text { mendukung potensi } \\
\text { pariwisata }\end{array} \\
\text { - } \begin{array}{l}\text { Belum tereksplorasinya } \\
\text { sistim pariwisata lokal } \\
\text { (desa) } \\
\text { - Belum adanya konsep } \\
\text { wisata yang dimunculkan }\end{array}\end{array}$ & $\begin{array}{l}\text { Alternatif strategi WO: } \\
\text { - Diperlukannnya sebuah } \\
\text { konsep perencanaan } \\
\text { wilayah desa target yang } \\
\text { terintegrasi (one village- } \\
\text { one theme) dengan konsep } \\
\text { pengembangan desa } \\
\text { Kabupaten Banyuwangi }\end{array}$ & $\begin{array}{l}\text { Alternatif strategi WT: } \\
\text { - Perlunya pengembangan } \\
\text { "skill individu" } \\
\text { masyarakat guna } \\
\text { menunjang perkembangan } \\
\text { wisata yang berkelanjutan } \\
\text { melalui program } \\
\text { pembinaan masyarakat } \\
\text { secara berkala } \\
\text { - Perlunya sebuah sistim } \\
\text { integrasi beberapa sektor } \\
\text { (transportasi-kesehatan- } \\
\text { wisata) guna menunjang } \\
\text { perkembangan wisata } \\
\text { berkelanjutan }\end{array}$ \\
\hline
\end{tabular}




\section{KESIMPULAN}

Hasil analisa data menunjukkan bahwa masing-masing desa mempunyai karakter yang unik, sehingga dapat menjadi kawasan wisata yang sesuai dengan karakter masing-masing. Desa Kenjo di Kecamatan Glagah menjadi desa penyangga penghasil bahan pertanian, Desa Gumuk berpotensi untuk bertransformasi menjadi kawasan wisata berbasis perikanan dan Desa Banjar sedang dalam tahap pengembangan menjadi desa wisata kuliner lokal.

\section{DAFTAR ISI}

[1] Pemerintah Kabupaten Banyuwangi. 2017. Investasi Sektor Pariwisata Tumbuh, Menpar Resmikan Resort Baru di Banyuwangi. Diunduh dari: https://www.banyuwangikab.go.id/beritadaerah/investasi-sektor-pariwisatatumbuh-menpar-resmikan-resort-baru-dibanyuwangi.html

[2] Putri, S.D., Soemarno, Hakim, L. Strategic Management of NatureBased Tourism on Ijen Creater in The Context of Sustainable Tourism Development. J.Ind. Tour. Dev. Std., Vol.3, No.3, pp. 123-129, 2015.

[3] Hamidi, H., Setijonegoro, F.X.N., Fujitriartanto, Sa'id, A., Harioso, Huda, Hardiyanto, A., Waluyanto, B., Lubis, I.S.G., Setiawan, D., Prayitno, H., Mu'arofah, A.F. Indeks Desa Membangun. Kementerian Desa, Pembangunan Daerah Tertinggal dan Transmigrasi: Jakarta Selatan, pp. 20-201, 2015.
[4] Salvatore, R., Chiodo, E., Fantini. A. Tourism transition in peripheral rural areas: Theories, issues and strategies. Annals of Tourism Research, vol. 68, pp. 41-51, 2018.

[5] BPS Kabupaten Banyuwangi. Kecamatan Glagah dalam Angka 2017. BPS Kabupaten Banyuwangi, pp. 1-54, 2017.

[6] BPS Kabupaten Banyuwangi. Kecamatan Daerah Licin dalam Angka 2017. BPS Kabupaten Banyuwangi, pp. 1-53, 2017.

[7] Valenti, W.C., Kimpara, J.M., Petro, B.L., Moraes-Valenti, P. Indicators of sustainability to assess aquaculture systems. Ecological indicators, vol 88, pp. 402-413, 2018.

[8] Omerzel, D.G. Innovatives in Tourism: Model Development. Procedia Economics and Finance, vol. 23, pp. 750756, 215.

[9] Adeyinka-Ojo, S. A strategic framework for analyzing employ ability skills deficits in rural hospitality and tourism destinations. Tourism Management Perspectives, vol. 27, pp. 47-54, 2018.

[10] Berg, P.O. Food - branding places - A sensory perspective. Place Branding and Public Diplomacy, vol. 0, pp. 16, 2015.

[11] Quan, S., Wang, N. towards a structural model of the tourist experience: an illustration from food experiences in tourism. Tourism management, vol. 25, pp. 297-305, 2015.

[12] Sengel, T., Karagoz, A., Cetin, G., Dincer, F.I., Ertugral, S.M., Balik, M. Tourists' Approach to Local Food. Procedia Social and Behavioral Science, vol. 195, pp. 429-437 